\title{
The nutrition of the veal calf
}

\section{4.* The effect of offering roughage on health and performance}

\author{
By J. H. B. ROY, I. J. F. STOBO, HELEN J. GASTON, \\ P. GANDERTON, SUSAN M. SHOTTON AND S. Y. THOMPSON \\ National Institute for Research in Dairying, Shinfield, Reading RG2 $9 A T$
}

$$
\text { (Received } 9 \text { fuly 1970-Accepted } 17 \text { March 1971) }
$$

\begin{abstract}
1. Eighteen bull calves, comprising twelve Ayrshires, three Friesians and three Jerseys were reared from birth to a slaughter weight equivalent to $22 \%$ of mature cow weight of the breed.

2. All the calves were given a milk substitute diet $a d l i b$. in two feeds daily. Six of the calves received this diet alone and the remaining twelve calves were offered roughage ad lib. from I week of age, either as meadow hay or as barley straw. The calf-house was maintained at a mean temperature of $23^{\circ}$ and a mean relative humidity of $62 \%$.

3. The mean total intake of meadow hay and barley straw over the experimental period of about 12 weeks was $3.0 \mathrm{~kg}$ and $0.4 \mathrm{~kg}$ respectively. Only three calves were consuming any meadow hay and only two calves any barley straw at 7 weeks of age.

4. The roughage consumed had no effect on the incidence of diarrhoea, on dry-matter intake from milk or on live-weight gain. All the calves offered meadow hay had lung lesions at slaughter. Severity of lung lesions in the Jersey and Friesian calves combined, but not in the Ayrshires, tended to be inversely related to the relative humidity to which they were exposed.

5. Dressed carcass weight and killing out percentage tended to be lower for the calves offered meadow hay. There was a highly significant inverse relationship between total intake of hay and killing out percentage. Perirenal fat deposition in relation to carcass weight was significantly lower and carotenoid content of the fat significantly higher for the calves offered the meadow hay. Skin weight per unit of slaughter weight ${ }^{\mathbf{0 . 7 3}}$ or carcass weight ${ }^{\mathbf{0 . 7 3}}$ was significantly greater for the calves given the mills substitute diet only.

6 . It is concluded that the calf shows very little desire to eat roughage when given a goodquality milk substitute diet $a d$ lib. and that, even when the amounts of roughage consumed are small, this has a deleterious effect on carcass quality.
\end{abstract}

The Brambell Committee (Brambell, r965) recommended that calves restricted to liquid diets for the production of veal should be offered palatable roughage from $\mathbf{I}$ week of age, so that their supposedly innate desire to ruminate should not be frustrated. Since, in veal production, dry food is usually withheld, an experiment was made to find the effect of offering roughage, in the form of either good-quality meadow hay or barley straw, on the performance and carcass quality of calves given a milk substitute diet $a d$ lib.

\section{METHODS \\ Plan of experiment}

The experiment of randomized block design was done with eighteen bull calves from April I 966 to February 1967 and consisted of three treatments in each of six blocks. Four blocks were of the Ayrshire breed and one each of the Jersey and Friesian breeds. The calves were removed from their dams before sucking and were placed on experiment within $8 \mathrm{~h}$ of birth. The treatments were as follows:

\begin{tabular}{|c|c|c|c|}
\hline Treatment no. & Colostrum & Milk substitute & Roughage available \\
\hline $\left.\begin{array}{l}1 \\
2 \\
3\end{array}\right\}$ & $\begin{array}{r}7 \mathrm{~kg} \text { whole } \\
\text { colostrum }\end{array}$ & $\begin{array}{l}20 \% \text { fat, high- } \\
\text { protein diet } \\
\text { ad lib. }\end{array}$ & $\left\{\begin{array}{l}\text { None } \\
\text { Meadow hay } \\
\text { Barley straw }\end{array}\right.$ \\
\hline
\end{tabular}




\section{Diets}

Colostrum. Each calf was given within $48 \mathrm{~h}$ of birth, $7 \mathrm{~kg}$ whole colostrum obtained from the first two milkings after parturition of Jersey, Ayrshire and Friesian cows.

Milk substitute. The chemical composition of the diet is given in Table $\mathrm{I}(a)$. The diet was prepared by homogenizing the appropriate quantity of non-vitaminized margarine (similar to that used by Roy, Shillam, Thompson \& Dawson, I96I) into liquid skim milk, which was pre-heated at a low temperature before spray-drying to prevent denaturation of the whey proteins. The diet was reconstituted by mixing I part powder with 6 parts water $(\mathrm{w} / \mathrm{w})$ to give a dietary dry-matter content of $13.7 \%$.

Table I. Composition of the milk substitute diet and of the meadow hay

(a) Milk substitute

Dry matter (\%)

Composition of dry matter (\%)

Fat

Protein $(\mathrm{N} \times 6.38)$

Lactose (anhydrous)

Ash

Calcium

Gross energy (kcal/g dry matter)

Supplements

Vitamin A (i.u./kg dry matter)

Vitamin $\mathrm{D}_{\mathbf{3}}$ (i.u./kg dry matter)

Vitamin $\mathrm{E}$ ( $\mathrm{mg} / \mathrm{kg}$ dry matter)

Magnesium (mg/kg dry matter)

Butylated hydroxyanisole $(\mathrm{mg} / \mathrm{kg}$ dry

matter) (b) Meadow hay

$\begin{aligned} \text { r3.7 } & \text { Dry matter (\%) } \\ & \text { Composition of dry matter }(\%) \\ 20.5 & \text { Ether extractives } \\ 29.9 & \text { Crude protein }(\mathrm{N} \times 6.25) \\ 39.5 & \text { Nitrogen-free extractive } \\ 6.6 & \text { Crude fibre } \\ 1 \cdot 1 & \text { Ash } \\ 5.2 & \text { Calcium } \\ & \\ 7250 & \\ 1813 & \\ 21 & \\ 238 & \\ 32 & \end{aligned}$

$84 \cdot 0$

$I \cdot 3$

I I. O

$48 \cdot I$

$29 \cdot 6$

10.0

0.6

The diet was supplemented with vitamins $\mathrm{A}, \mathrm{D}_{3}$ and $\mathrm{E}$, with $\mathrm{MgCl}_{2} \cdot 6 \mathrm{H}_{2} \mathrm{O}$ and with the antioxidant butylated hydroxyanisole, as shown in Table $\mathrm{r}$. All the calves were given a total supplement of ${ }_{5} 500 \mathrm{mg} \mathrm{Fe}$ in the form of $5 \mathrm{ml} \mathrm{Fe}$ dextran, containing $100 \mathrm{mg} \mathrm{Fe} / \mathrm{ml}$ (Imposil 200; Fisons Pharmaceuticals Ltd, Loughborough) injected intramuscularly on the 7 th, I4th and 21 st days of age, as described by Roy, Gaston, Shillam, Thompson, Stobo \& Greatorex (1964).

Meadow hay and barley straw. The hay or barley straw was offered from I week of age, and the intake was recorded weekly. The composition of the hay is given in Table I $(b)$. Drinking water was not offered to the calves.

\section{Calves}

The collection and management of the calves was as described by Roy, Stobo, Gaston \& Greatorex (1970). The calves were reared in single pens in the controlledenvironment calf-house described by Roy, Stobo, Gaston, Ganderton, Shotton \& Ostler (1971), at a planned temperature of $20^{\circ}$. The mean environmental temperature and relative humidity in the calf-house were $22.8^{\circ}$ and $6 \mathrm{I} \cdot 8 \%$ respectively, with a range for the mean values to which individual calves were exposed of $22 \cdot 3^{-23} \cdot 2^{\circ}$ and $48 \cdot 7-65 \cdot 0 \%$ for environmental temperature and relative humidity respectively.

The milk substitute was given ad lib. in two feeds daily and the calves were 
slaughtered at $22 \%$ of mature cow weight of the breed (Foot \& Roy, 1967), the live weights being: Jersey, $90 \mathrm{~kg}$; Ayrshire, I $8 \mathrm{~kg}$; Friesian, I36 kg. The calves were slaughtered on the Tuesday after the appropriate weight was reached. No milk was given on the morning of slaughter and only half the normal allowance was offered at the evening feed on the day before slaughter. Hay and straw were removed at 17.00 hours on the day before slaughter of the calves on treatments 2 and 3 respectively. The weights of carcass, skin and perirenal fat were recorded, and a sample of the perirenal fat was removed for determination of carotenoid content. The degree of consolidation in the tissues of the lungs was assigned a score (Roy, Stobo \& Gaston, 1970).

\section{Analytical methods}

For the measurement of carotenoids in the perirenal fat, the fat was extracted by a modification of the method of Olson, Hegsted \& Peterson (1939) and saponified. A suitable dilution of the non-saponifiable residue in chloroform was used for the determination of carotenoids by the antimony trichloride reaction. The absorption measurements were made in the photoelectric spectrophotometer of Thompson (I949).

\section{RESULTS}

Mortality. One Jersey calf that was offered barley straw died at $35 \mathrm{~d}$ of age, having consumed $200 \mathrm{~g}$ straw. This calf did not receive its first feed of colostrum until I $_{5} \cdot \mathbf{h}$ after birth owing to a delayed notification of birth. Post-mortem examination showed that the calf had an acute abomasitis and enteritis, particularly affecting the colon.

Table 2. Effect of offering meadow hay or barley straw on the health of calves given milk substitute ad lib. in two feeds daily

(Mean values with their ranges or pooled standard errors)

\begin{tabular}{|c|c|c|c|c|}
\hline & \multicolumn{3}{|c|}{ Treatment no. and details } & \multirow[b]{2}{*}{$\begin{array}{l}\text { Pooled SE } \\
\text { of mean }\end{array}$} \\
\hline & $\begin{array}{l}\text { I } \\
\text { No roughage } \\
\text { offered }\end{array}$ & $\begin{array}{l}{ }^{2} \\
\text { offered }\end{array}$ & $\begin{array}{l}\text { B } \\
\text { Barley straw } \\
\text { offered }\end{array}$ & \\
\hline $\begin{array}{l}\text { No. of calves } \\
\text { No. of d on which calves had } \\
\text { diarrhoea: }\end{array}$ & 6 & 6 & 6 & \\
\hline Birth to $14 \mathrm{~d}$ & $0(0-1)$ & 0 & $\circ$ & - \\
\hline $\begin{array}{l}\text { Birth to slaughter } \\
\text { No. of } \mathrm{d} \text { on which calves had a } \\
\text { high rectal temperature } \\
\left(>39^{\circ} 33^{\circ}\right) \dagger \text { : }\end{array}$ & $3 \cdot 0(0-1)$ & $1 \cdot 5(0-5)$ & $2.7(0-14)$ & - \\
\hline $\begin{array}{l}\text { Birth to } 14 \mathrm{~d} \\
\text { Birth to slaughter }\end{array}$ & $\begin{array}{l}2 \cdot 3(0-9) \\
4 \cdot 7(1-14)\end{array}$ & $\begin{array}{l}4 \cdot 0(r-6) \\
6 \cdot 3(4-10)\end{array}$ & $\begin{array}{l}3 \cdot 0(0-5) \\
6.7(3-12)\end{array}$ & - \\
\hline $\begin{array}{l}\text { Mean rectal temperature }\left({ }^{\circ} \mathrm{C}\right) \\
\text { (birth-slaughter) }\end{array}$ & $39 \cdot$ II & $39 \cdot 22$ & $39 \cdot 33$ & 0.072 \\
\hline $\begin{array}{l}\text { Percentage of calves with lung } \\
\text { lesions at slaughter }\end{array}$ & $5 \circ$ & 100 & 33 & 一 \\
\hline $\begin{array}{l}\text { Severity of lung lesions at } \\
\text { slaughter (score o-5) }\end{array}$ & $x \cdot 5$ & $1 \cdot 8$ & $x \cdot 8$ & 0.57 \\
\hline
\end{tabular}


There was also a bilateral pneumonia in the apical lobes, from which Escherichia coli, Streptococcus and Proteus spp. organisms were isolated. In addition, there was a nephritis and polyarthritis with erosion of the articular cartilage (D. C. Ostler, 1966, personal communication). This calf was replaced.

Incidence of diarrhoea and of a high rectal temperature $\left(>39^{\circ} 33^{\circ}\right)($ Table 2$)$. There was no significant difference in the incidence of diarrhoea or of a high rectal temperature between treatments during the first $\mathrm{i} 4 \mathrm{~d}$ of life or over the whole experimental period. Mean rectal temperature tended to be higher for the calves offered roughage, but the difference was not significant.

Incidence and severity of lung lesions at slaughter (Table 2). Although the incidence of lung lesions was $100 \%$ for the calves offered meadow hay, and tended to be higher than that for the calves on the other two treatments, the difference was not statistically significant. Sixty-seven per cent of both the Friesian and Ayrshire calves had lung lesions at slaughter, compared with $100 \%$ for calves of the Jersey breed. The severity of lung lesions tended to be greatest in the Jersey and least in the Friesian breed.

At the high environmental temperature used in the present experiment $\left(23^{\circ}\right)$ the severity of lung lesions tended to be inversely related to the relative humidity to which individual calves were exposed. The combined relationship for all breeds and diets was:

$$
Y=12 \cdot 9-0 \cdot 182 x \quad\left(S D=I^{\prime} \cdot 5^{1} 7\right),
$$

where $Y=$ severity of lung lesions at slaughter (score $0-5$ ) and $x=$ relative humidity $(\%)$. The relationship was not significant for individual breeds, but the pooled results for the Jersey and Friesian calves approached significance and gave a similar relationship to that shown for the pooled results for all breeds.

Severity of lung lesions was not significantly related to mean rectal temperature, to incidence of a high rectal temperature, to live-weight gain, or to skin weight/carcass weight ${ }^{0.73}$.

Birth weight and intake of milk substitute (Table 3 ). Birth weight was significantly higher for calves offered barley straw. Although the total intake of dry matter from the milk substitute was highest for the calves that were not offered roughage, this was the result of the greater mean age of these calves at slaughter. Daily dry-matter intake from the milk substitute did not differ between treatments $x$ and 2 , but the mean value for treatments $I$ and 2 combined was significantly lower than that for calves on treatment 3 . Although this was probably a reflection of the higher mean birth weight of the calves on treatment 3 , no significant relationship existed between daily dry-matter intake from the milk substitute and birth weight.

Intake of meadow hay and barley straw (Table 3). The total amount of hay consumed during the experimental period ranged from 340 to $8160 \mathrm{~g}$ dry matter for individual calves, the second highest consumption being $3400 \mathrm{~g}$ dry matter, whereas the amount of barley straw consumed ranged from zero to $850 \mathrm{~g}$ dry matter. The individual intakes of roughage in relation to age are given in Table 4. Only three calves were consuming hay and only two calves barley straw at 7 weeks of age.

Live-weight gain and efficiency of food conversion (Table 3 ). No significant differences 


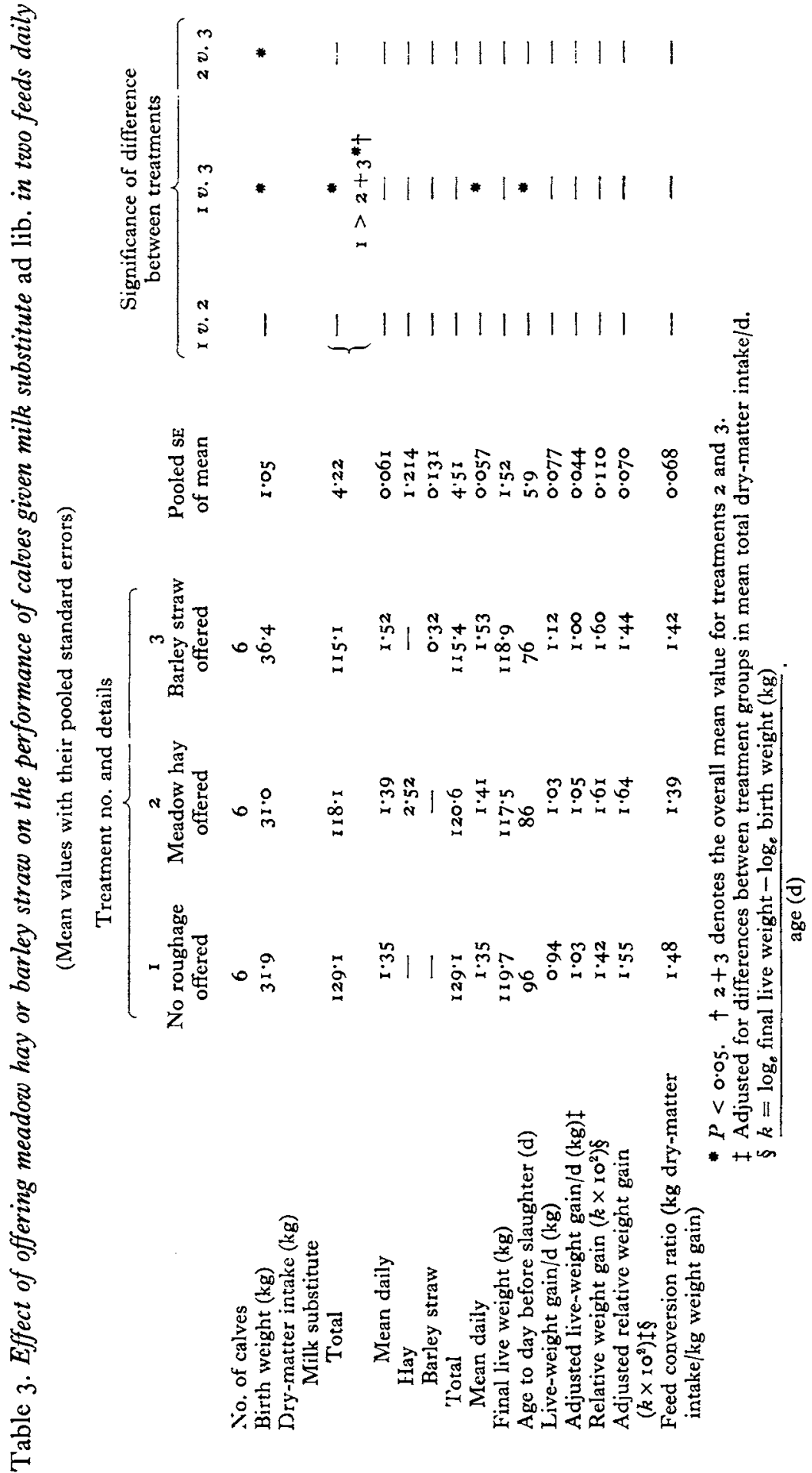




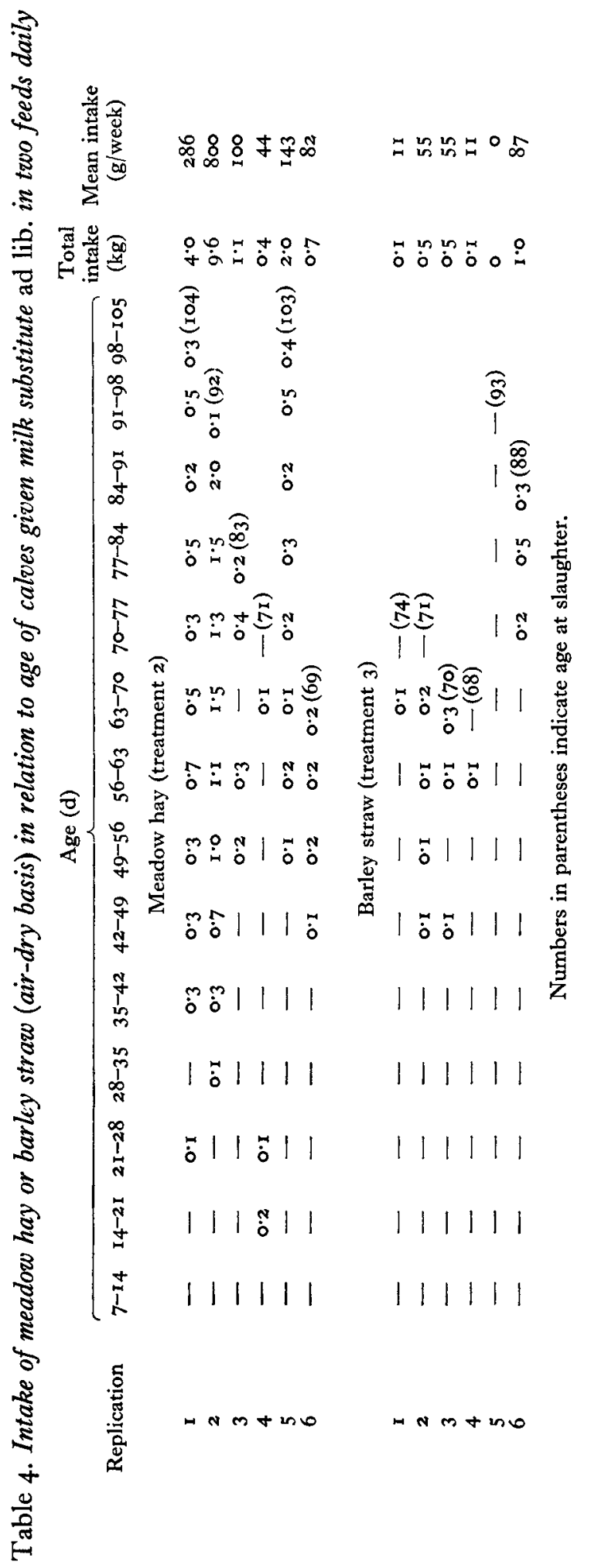


Vol. 26
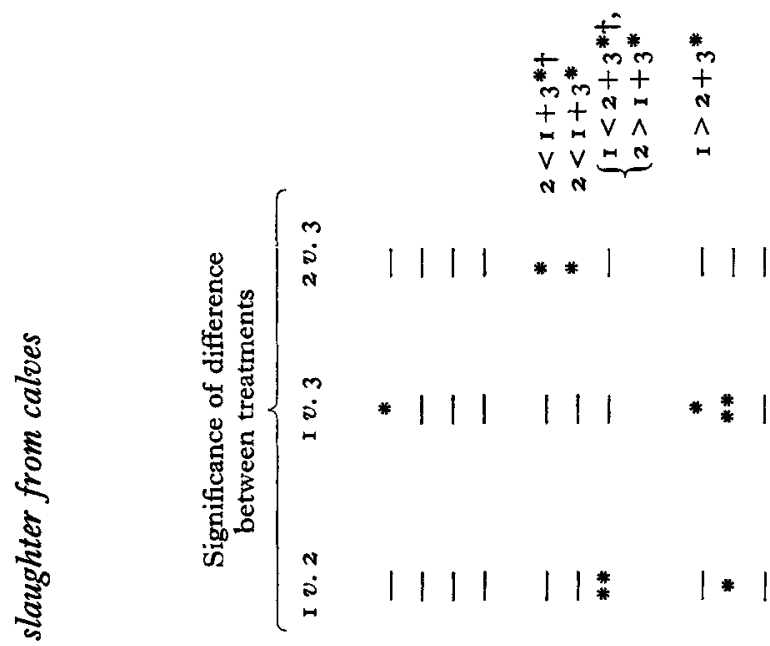

2

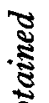

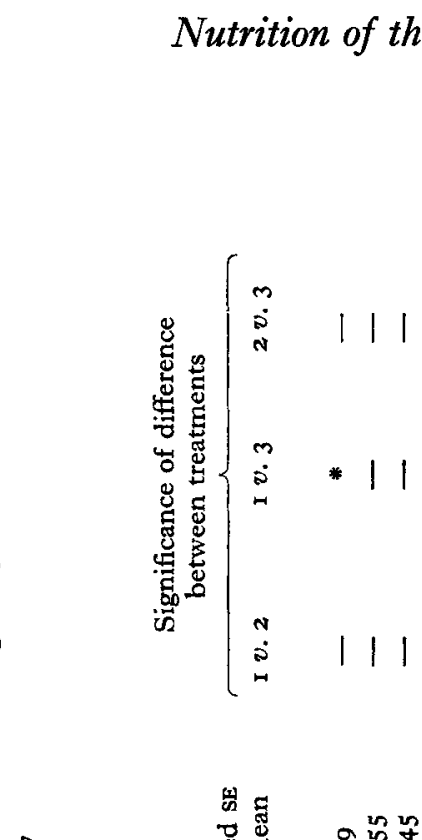

เ

5

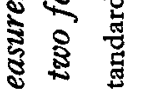

¿

ธิ 을 要

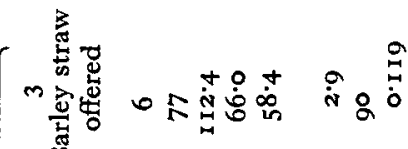

त

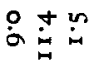

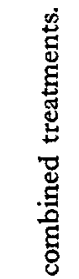

ن용

$R$ 要

है

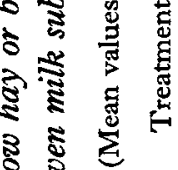

कृ

:

离

के

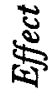

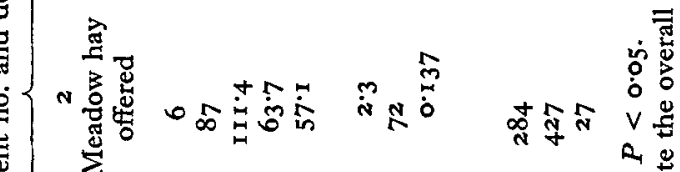

*

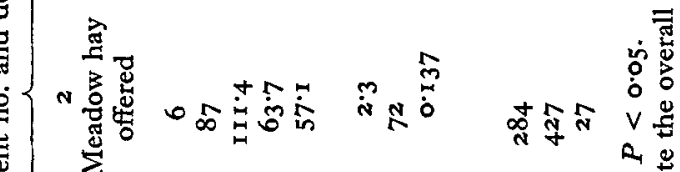

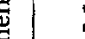

(

*

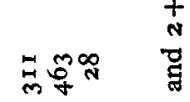

事

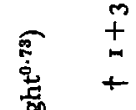

in

营

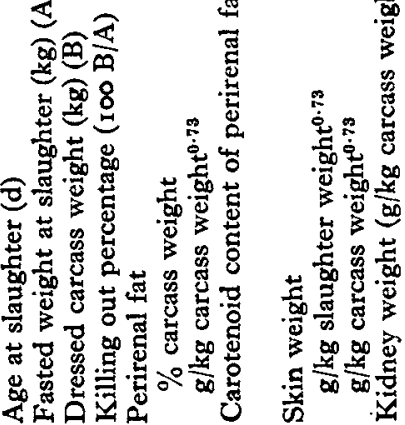


occurred between treatments for final live weight, live-weight gain/d, or relative weight gain. After adjustment for differences between treatment groups for total drymatter intake/d, there was still no difference between treatments in live-weight gain/d or relative weight gain. Feed conversion ratio ( $\mathrm{kg}$ dry matter eaten $/ \mathrm{kg}$ weight gain) tended to be lowest for calves offered the meadow hay, a finding probably associated with differences in gut-fill.

Dressed carcass weight and killing out percentage (Table 5). Dressed carcass weight and killing out percentage tended to be lowest for the calves offered meadow hay although the differences failed to reach significance. However, there was a highly significant inverse relationship $(P<0.01)$ between intake of roughage and killing out percentage, barley straw having a significantly greater effect than meadow hay, as shown by the following regression equations:

$$
\begin{array}{ll}
Y=58.9-0.710 x_{1} & (\mathrm{SD}=0.964), \\
Y=60.4-6.355^{x_{2}} & (\mathrm{SD}=2.047),
\end{array}
$$

where $Y=$ killing out percentage, $x_{1}=$ total dry-matter intake as meadow hay $(\mathrm{kg})$ and $x_{2}=$ total dry-matter intake as barley straw $(\mathrm{kg})$.

Perirenal fat deposition and carotenoid content of the fat (Table 5). Perirenal fat deposition as a percentage of carcass weight or in relation to metabolic body-weight $\left(\mathrm{kg}^{0.73}\right)$ was significantly less for calves offered meadow hay than for those given no roughage, or offered barley straw. The ratio of perirenal fat to carcass weight ${ }^{0 \cdot 73}$ was unaffected by the environmental temperature to which the calves were exposed, but tended to be positively related to relative humidity.

The carotenoid content of the perirenal fat was significantly higher for the calves offered the meadow hay; the calves offered barley straw had a value intermediate between the values for the other two treatments.

Skin weight and kidney weight (Table 5). Skin weight per unit of slaughter weight ${ }^{0.73}$ or carcass weight ${ }^{0.73}$ was significantly greater for the calves restricted to a milk substitute diet. This difference was not associated with differences between treatment groups in mean age at slaughter or with differences in perirenal fat deposition per unit of carcass weight ${ }^{0.73}$, as had been shown in an earlier experiment of Roy et al. (1971). Although these workers found an inverse relationship between severity of lung lesions and skin weight in calves maintained at a high environmental temperature, no relationship was found in the present experiment between severity of lung lesions and skin weight/carcass weight $\mathrm{t}^{0.73}$. However, the calves on treatment $\mathrm{I}$, which tended to have the lowest severity of lung lesions, also had the highest skin weight.

Kidney weight per unit of carcass weight $t^{0.73}$ did not differ between treatments.

\section{DISCUSSION}

This experiment has clearly shown that calves given an ad lib. intake of a milk substitute of the composition used in this experiment and injected with a total of $1.5 \mathrm{~g}$ Fe will consume very little roughage, in the form of either meadow hay or barley straw. However, even a small amount of hay tends to reduce feed conversion ratio 
and, by reducing perirenal fat deposition and increasing gut-fill, reduces the killing out percentage. Moreover, the carotenoid content of the perirenal fat, and thus its yellow pigmentation, was increased when roughage was given. The combination of such factors has a deleterious effect on the carcass quality of calves intended for quality veal production.

The effect of meadow hay in the diet in reducing perirenal fat deposition, and thus probably also total carcass fat deposition, cannot be explained unless an interaction occurred between the fat in the diet and some metabolite produced in the rumen as a result of rumen development. If, however, some of the milk substitute failed to by-pass the rumen, the efficiency of energy utilization would be reduced, although observations in this and subsequent experiments (Stobo \& Roy, unpublished) would suggest that this was not so. The tendency for rectal temperature to be higher in calves offered roughage may show the effect of the heat produced during fermentation of the small amount of roughage consumed. Possibly the acetic acid that would predominantly have been produced in the rumen when roughage was given allowed some of the fat in the milk substitute to be metabolized for energy purposes. This is in contrast to the finding that fat in milk substitute diets is not normally available as a source of energy for bringing about an increase in nitrogen retention (Roy, Stobo, Gaston \& Greatorex, 1970; Roy, Stobo \& Gaston, 1970). The reduction in skin weight when roughage was offered could similarly be the result of a reduction in the subcutaneous fat content of the skin.

The high incidence of lung lesions in the calves offered meadow hay was unexpected, since there were no clinical symptoms of pneumonia in these calves and the incidence of a high rectal temperature was not significantly greater than that in calves on the other treatments. Moreover, no relationship could be established between severity of lung lesions and the incidence of a high rectal temperature, or live-weight gain. However, experiments in which calves were inoculated with viruses or mycoplasmas have, in many instances, failed to produce clinical symptoms of pneumonia, although pneumonic lesions were observed in the lungs at autopsy (Stevenson \& Hore, 1970; Gourlay \& Thomas, 1970). In general, it is recognized that the initial virus infection may cause only mild clinical symptoms (Bittle, 1970), but that in practice secondary infections by bacteria, such as Pasteurella spp. (Bittle, r970; Gale, 1970; Gourlay, Mackenzie \& Cooper, 1970) frequently give rise to more severe clinical symptoms. In the present experiment, it is not known whether the lung lesions resulted from infections by viruses alone, or in combination with bacteria or other factors, but the possibility cannot be ruled out that dust or fungal spores inhaled from the hay may have caused irritation to the lungs of otherwise healthy calves, as suggested by Lacey (1968); the more dusty nature of the hay than of the straw gives support to this explanation.

The finding that an increase in relative humidity reduced the severity of lung lesions, especially in calves of the Jersey and Friesian breeds, is in keeping with observations made at an environmental temperature of $2 \mathrm{I}^{\circ}$ in an experiment designed to study the effect of environmental temperature on the performance and health of the calf. This relationship between relative humidity and severity of lung lesions is, however, rather 
complex, since at an environmental temperature of $14.5^{\circ}$ the severity of lung lesions was found to increase with increase in relative humidity in calves of the Jersey and Friesian breed (Roy et al. I971).

From the results of the present experiment, it is clear that the calf shows very little desire to consume roughage when given a good-quality milk substitute diet ad lib. and that even the small amount of roughage that is consumed has a deleterious effect on carcass quality. Access to hay may also have an effect on the incidence of lung lesions. In consequence, the findings of this experiment do not support the recommendations of the Brambell Committee (Brambell, ${ }^{2} 6_{5}$ ) on the use of roughage for veal calves.

We are indebted to the Veterinary Investigation Centre, Coley Park, Reading, for carrying out the post-mortem examination.

\section{REFERENCES}

Bittle, J. L. (1970). Y. Dairy Sci. 53, 625.

Brambell, F. W. R. (1965). Report of the Technical Committee to Enquire into the Welfare of Animals kept under Intensive Livestock Husbandry Systems [Cmnd 2836]. London: H.M. Stationery Office.

Foot, A. S. \& Roy, J. H. B. ( 1967$)$. Cattle in Chambers Encyclopaedia 4 th ed. London: Chambers.

Gale, C. (1970). F. Dairy Sci. 53, 62 I.

Gourlay, R. N., Mackenzie, A. \& Cooper, J. E. (1970). F. comp. Path. 80, 575.

Gourlay, R. N. \& Thomas, L. H. (1970). $\mathcal{F . ~ c o m p . ~ P a t h . ~ 8 0 , ~} 585$.

Lacey, J. (1968). F. gen. Microbiol. 51, I73.

Olson, F. R., Hegsted, D. M. \& Peterson, W. H. (1939). F. Dairy Sci. 22, 63.

Roy, J. H. B., Gaston, H. J., Shillam, K. W. G., Thompson, S. Y., Stobo, I. J. F. \& Greatorex, J. C. (1964). Br. $\mathcal{~}$. Nutr. 18, 467.

Roy, J. H. B., Shillam, K. W. G., Thompson, S. Y. \& Dawson, D. A. (r96r). Br. F. Nutr. I5, 54r.

Roy, J. H. B., Stobo, I. J. F. \& Gaston, H. J. (1970). Br. F. Nutr. 24, 459.

Roy, J. H. B., Stobo, I. J. F., Gaston, H. J., Ganderton, P., Shotton, S. M. \& Ostler, D. C. (I97I) Br. F. Nutr. 26, 363 .

Roy, J. H. B., Stobo, I. J. F., Gaston, H. J. \& Greatorex, J. C. (1970). Br. F. Nutr. 24, 441.

Stevenson, R. G. \& Hore, D. E. (I970). F. comp. Path. 8o, 6r 3.

Thompson, S. Y. (1949). Br. Y. Nutr. 3, 43 . 